\title{
PENGARUH KOMBINASI ARANG AKTIF DENGAN URIN SAPI PERAH TERHADAP PRODUKTIVITAS RUMPUT BENGGALA (Panicum maximum Jacq)
}

\author{
(The Effect Of Actived Charcoal With Urin Dairy Cow Combination On Productivity Of \\ Benggala Grass(Panicum maximum Jacq)
}

\author{
Roman Antonius Pegi ${ }^{1}$,Marlina Eulis Tanti ${ }^{2}$, Mustafa Herryawan Kemal $^{2}$ \\ ${ }^{1}$ Mahasiswa Pascasarjana Program Studi Ilmu Peternakan Fakultas Peternakan Universitas Padjadjaran, \\ Jl.Raya Bandung Sumedang KM.21, Hegarmanah, Jatinangor,Kabupaten Sumedang, Jawa Barat 45363, \\ Indonesia, Telepon: (022) 7798241, Faksimile: (022) 7798212 \\ ${ }^{2}$ Dosen Program Studi Ilmu Peternakan Fakultas Peternakan Universitas Padjadjaran, Jl.Raya Bandung \\ Sumedang KM.21, Hegarmanah, Jatinangor,Kabupaten Sumedang, Jawa Barat 45363, Indonesia, \\ Telepon: (022) 7798241, Faksimile: (022) 7798212 \\ Email:romanpegi@gmail.com
}

Article Submitted : 31-07-2019

Article Accepted : 03-10-2019

\begin{abstract}
Benggala grass production is determined by soil fertility. The use of activated charcoal can increase soil nutrients. The purpose of the study was to determine the effect of activated charcoal on the growth and productivity of Benggala grass. The material used in this study consisted of activated charcoal (rice husk, corn cobs, coconut shell), urine of dairy cows and soil. The research method used a completely randomized factorial $3 \times 3$ design consisting of factor A (active charcoal dose), namely D1: $0 \%$ dose (control), D2: $2.5 \%$ dose, D3: $5 \%$ dose while factor B (activated charcoal type) namely : J1: Actived charcoal type of rice husk, J2: Type of actived corncob charcoal, J3: The type of coconut shell activated charcoal is further tested by using Duncan Multiple Range Test (DMRT) with a significant level of 5\%. The parameters measured were plant height, number of tillers, fresh weight of leaves, dry weight of leaves carried out in the first cutting period (age 45 HST) and cutting II (age 90 HST), crude protein, crude fiber carried out on cutting I and fresh weight of roots and root dry weight was carried out in cutting II. The results showed $2.5 \%$ and $5 \%$ activated charcoal doses increased plant height, number of tillers, fresh weight of leaves, dry weight of leaves, crude fiber content, fresh weight of roots and dry weight of Benggala grass roots. The activedcharcoalof rice husk gives the best results on the growth and productivity of Bengal grass.
\end{abstract}

Keywords : Benggala grass, active charcoal, urine of dairy cows

\section{PENDAHULUAN}

Rumput memiliki peranan penting untuk menyediakan makanan bagi ternak ruminansia di Indonesia (Kusuma, 2017). Produksi rumput Benggala meningkat saat musim hujan namun musim kemarau produksinya menurun sehingga ketersediaan makanan ternak ruminansia berkurang (Dhalikaet al., 2015). Salah satu jenis tanaman yang umum digunakan sebagai pakan sumber hijauan adalah rumput Benggala. Rumput ini termasuk tanaman pakan berumur panjang, dapat beradaptasi pada semua jenis tanah, tahan terhadap naungan dan palatabel atau disukai ternak (Widanaet al., 2015). Rumput Benggala (Panicum maximumJacq.) merupakan jenis rumput pakan ternak unggul di Indonesia dan 
dapat tumbuh hingga ketinggian $2000 \mathrm{~m} \mathrm{dpl,}$ serta baik untuk ditanam bersama legum. Hasil hijauan rumput Benggala dipengaruhi oleh interaksi pupuk kandang $\mathrm{x}$ sumber nitrogen rumput Benggala termasuk tanaman yang responsif terhadap pemberian nitrogen seperti halnya Gramineae lainnya (Purbajantiet al., 2010).

Arang aktif merupakan bahan alternative untuk perbaikan kesuburan tanah seperti sifat kimia, fisik, dan biologi tanah (Sismiyantiet al., 2018). Arang aktif sekam padi mampu memperbaiki tanah dan meningkatkan produktivitas tanaman (Mirantiet al., 2016). Produksi arang aktif dari biomassa tempurung kelapa sebagai salah satucara yang efektif untuk mendaur ulang sumberdaya limbah (Angalaeeswari dan Kamaludeen, 2017). Tongkol jagung diduga memiliki senyawa-senyawa aktif yang dapat berpotensi untuk dikembangkan (Dewi dan Inaratul, 2016).Urin sapi dimanfaatkan sebagai pupuk organik cair karena mengandung unsur hara yang dibutuhkan oleh tanaman (Alfarisi danManurung 2015). Pemanfaatan arang aktif selama ini hanya diterapkan pada tanaman pertanian sehingga penelitian ini bertujuan untuk mengetahui pengaruh arang aktif dicampur urin sapi perah terhadap pertumbuhan dan produktivitas rumput Benggala.

\section{METODE PENELITIAN}

Bahan yang digunakan dalam penelitian ini terdiri dari: 100 pols rumput Benggala (Panicum maximum Jacq), Arang aktif sekam padi $5 \mathrm{~kg}$, Arang aktif tongkol jagung $5 \mathrm{~kg}$, Arang aktif tempurung kelapa 5 $\mathrm{kg}$, Urin sapi perah murni 13 liter, tanah yang diayak $250 \mathrm{~kg}$.

\section{Tahap I Pembuatan arang aktif}

Limbah seperti sekam padi, tempurung kelapa dan tongkol jagung dilakukan pembakaran secara bertahap menggunakan drum besi sampai berubah bentuk menjadi arang. Proses aktivasi arang dilakukan secara fisik dengan cara ditumbuk menggunakan lesung hingga terlihat halus dan diayak untuk menyeragamkan kehalusan. Selanjutnya dijemur dibawah sinar matahari selama 2 hari. Metode pengambilan urin sapi perah dilakukan secara langsung. Setiap jenis arang aktif dengan ukuran $5 \mathrm{~kg}$ dicampur 3 liter urin sapi perah untuk proses fermentasi yang disimpan di dalam tong plastic selama 2 minggu dengan kondisi udara anaerob. Hasil fermentasi dikeluarkan lalu dikeringkan dengan sinar matahari selama 1 hari.

Tahap II Pengambilan tanah, pencampuran media tanam, Penanaman dan Pengukuran Parameter

Tanah yang digunakan dalam penelitian ini berasal dari lahan laboratorium tanaman makanan ternak Fakultas Peternakan,Universitas Padjadjaran. Tanah disaring menggunakan alat pengayak. Kemudian tanah ditimbang sebanyak $5 \mathrm{~kg}$ dan dicampur dengan setiap jenis arang aktif sesuai dengan susunan perlakuan. Penanaman menggunakan pot dengan masing-masing pot ditanam 2 pols rumput yang berukuran $15 \mathrm{~cm}$ dengan lubang tanam $\pm 3 \mathrm{~cm}$. Penanaman dilaksanakan selama 90 hari dengan waktu pemotongan sebagai berikut pemotongan I 45 hari dan pemotongan II 90 hari. Parameter pengukuran terdiri dari tinggi tanaman, jumlah anakan, berat segar daun, berat kering daun (Diukur pada pemotongan I) sedangkan protein kasar, serat kasar, berat segar akar, berat kering akar (Diukur pada pemotongan II).

\section{Metode Dan Analisis Data}

Rancangan yang digunakan dalam penelitian ini model rancangan acak lengkap (RAL) pola faktorial terdiri dari faktor A adalah dosis arang yaitu: (D1): Dosis 0\% (kontrol), (D2): Dosis 2,5\%,(D3): Dosis $5 \%$ Sedangkan faktor B adalah jenis arang yaitu: (J1): Jenis arang aktif sekam padi, (J2): Jenis arang aktif tongkol jagung, (J3): Jenis arang aktif tempurung kelapa. Data hasil pengamatan dianalisis dengan menggunakan sidikragam (Anova) RAL pola faktorial dengan uji lanjut Duncan Multiple Range 
Test (DMRT) tingkat signifikan 5\%. Analisis data menggunakan program SPSS Statistics21.

\section{HASIL DAN PEMBAHASAN}

\section{Tinggi Tanaman}

Pertumbuhan rumput Benggala dipengaruhi oleh penambahan arang aktif pada media tanam. Penggunaan arang aktif tongkol jagung 5\% menghasilkan tinggi tanaman terbaik (Tabel2). Hal ini dapat diduga kandungan nitrogen $0,92 \%$ yang terdapat dalam arang aktif tongkol jagung lebih banyak dibutuhkan untuk pertumbuhan dan perkembangan tanaman (Tabel 1)

Tabel 1. Hasil analisis laboratorium arang aktif yang diperkaya urin sapi perah

\begin{tabular}{|c|c|c|c|c|}
\hline \multirow{2}{*}{$\begin{array}{l}\text { Kandungan } \\
\text { Unsur hara }\end{array}$} & \multirow[b]{2}{*}{ Satuan } & \multicolumn{3}{|c|}{ Jenis arang aktif } \\
\hline & & $\begin{array}{l}\text { Sekam } \\
\text { Padi }\end{array}$ & $\begin{array}{c}\text { Tongkol } \\
\text { Jagung }\end{array}$ & $\begin{array}{c}\text { Tempurung } \\
\text { Kelapa }\end{array}$ \\
\hline C-organik & $(\%)$ & 22,15 & 25,86 & 24,63 \\
\hline $\mathrm{C} / \mathrm{N}$ & $(-)$ & 25,46 & 28,11 & 37,32 \\
\hline Kadar Air & $(\%)$ & 9,53 & 14,70 & 33,13 \\
\hline \multicolumn{5}{|l|}{ T'otal : } \\
\hline $\mathrm{N}$ & $(\%)$ & 0,87 & 0,92 & 0,66 \\
\hline $\mathrm{P} 2 \mathrm{O} 5$ & $(\%)$ & 0,00 & 0,44 & 0,04 \\
\hline $\mathrm{K} 2 \mathrm{O}$ & $(\%)$ & 0,80 & 1,74 & 1,55 \\
\hline
\end{tabular}

Sumber : Laboratorium Kimia Tanah Dan Nutrisi Tanaman Departemen Ilmu Tanah dan Sumber Daya Lahan Fakultas Pertanian Universitas Padjadjaran.

Salah satu sumberdaya dalam tanah yang mendukung pertumbuhan dan perkembangan tanaman merupakan ketersediaan unsur hara pada tanah, terutama nitrogen yang merupakan salah satu unsur hara makro yang penting bagi tanaman yang diperlukan dalam pertumbuhan bagianbagian vegetatif seperti akar, batang, dan daun (Arifet al., 2014). Arang aktif tongkol jagung yang dicampur dengan pupuk urea di tanah netral dapat meningkatkan tinggi tanaman jagung pada umur 8 minggu (Hadi dan Wani, 2018).

Arang aktif pada media tanah terutama tingkat aplikasi yang tinggi dapat meningkatkan pertumbuhan tanaman dan peningkatan ketersediaan air (Alburquerqueetal., 2014). Penggunaan arang aktif tongkol jagung $2 \%$ dapat meningkatkan pertumbuhan dan produksi tanaman jagung di tanah Alfisols selama 40 hari (Albert dan Kwame, 2018).

Tinggi rumput Benggala menunjukkan arang aktif tempurung kelapa 5\% memiliki nilai lebih tinggi dari semua jenis arang aktif (Tabel2). Arang aktif tempurung kelapa mengandung kadar air dan $\mathrm{C} / \mathrm{N}$ lebih tinggi dari pada arang aktif sekam padi dan arang aktif tongkol jagung (Tabel 1).

Tabel 2. Pengaruh arang aktif terhadap tinggi tanaman

\begin{tabular}{|c|c|c|c|c|c|}
\hline $\begin{array}{c}\text { Waktu } \\
\text { Pengamatan }\end{array}$ & $\begin{array}{c}\text { Dosis } \\
\text { Arang aktif }\end{array}$ & \multicolumn{4}{|c|}{ Jenis arang aktif } \\
\hline (HST/cm) & $(\%)$ & $\begin{array}{l}\text { Sekam } \\
\text { Padi }\end{array}$ & Tongkol Jagung & $\begin{array}{c}\text { Tempurung } \\
\text { Kelapa }\end{array}$ & Rerata \\
\hline \multirow{4}{*}{45} & 0 & $61,63^{\mathrm{a}}$ & $50,50^{\mathrm{a}}$ & $57,88^{\mathrm{a}}$ & $56,67^{\mathrm{a}}$ \\
\hline & 2,5 & $54,88^{\mathrm{a}}$ & $81,13^{\mathrm{b}}$ & $68,75^{\mathrm{ab}}$ & $68,25^{\mathrm{b}}$ \\
\hline & 5 & $80,38^{a}$ & $86,63^{\mathrm{a}}$ & $75,00^{\mathrm{a}}$ & $80,67^{c}$ \\
\hline & Rerata & $65,63^{\mathrm{a}}$ & $72,75^{\mathrm{a}}$ & $67,21^{\mathrm{a}}$ & \\
\hline
\end{tabular}




\begin{tabular}{cccccc}
\hline & 0 & $84,50^{\mathrm{a}}$ & $68,50^{\mathrm{a}}$ & $75,25^{\mathrm{a}}$ & $76,08^{\mathrm{a}}$ \\
90 & 2,5 & $77,88^{\mathrm{a}}$ & $86,50^{\mathrm{a}}$ & $81,25^{\mathrm{a}}$ & $81,88^{\mathrm{a}}$ \\
& 5 & $102,13^{\mathrm{a}}$ & $93,00^{\mathrm{a}}$ & $111,13^{\mathrm{a}}$ & $102,08^{\mathrm{b}}$ \\
\cline { 2 - 5 } & Rerata & $88,17^{\mathrm{a}}$ & $82,67^{\mathrm{a}}$ & $89,21^{\mathrm{a}}$ &
\end{tabular}

Keterangan: Angka yang diikuti huruf yang sama menunjukan hasil berbeda tidak nyata dengan uji lanjut Duncan Multiple Range Test (DMRT) dengan tingkat signifikan 5\% dan HST: Hari Setelah Tanam.

Hasil penelitian Angalaeeswari dan Kamaludeen (2017) melaporkan tempurung kelapa memiliki $p H$ 8,66, Cation exchange capacity11,93 $\mathrm{cmol}\left(p^{+}\right) \mathrm{kg}^{-1}$, Particle size $56,4 \mathrm{~nm}$ dan Pore space 31,01\% sehingga dapat diduga arang aktif tempurung kelapa lebih banyak menyerap air yang dibutuhkan oleh tanaman dan kandungan $\mathrm{C} / \mathrm{N}$ tidak mudah lapuk akibat ukuran tekstur partikel yang keras.

Pengaruh arang aktif ke tanah bermanfaat untuk meningkatkan kualitas tanah dan mempertahankan nutrisi, sehingga meningkatkan pertumbuhan tanaman (Bonanomiet al., 2017). Hasil penelitian Tribuyeniet al., (2016) melaporkan bahwa penambahan arang aktif tempurungkelapa 6 ton ha ${ }^{-1}$ dicampur dosis pupuk organic cair 8 cc $\mathrm{L}^{-1}$ air terhadap tanaman kubis bunga(Brassica oleraceae var. botrytis L.) meningkatkan tinggi tanaman pada umur 5 minggu setelah tanam (MST).

\section{Jumlah Anakan}

Penambahan arang aktif sekam padi dosis $2,5 \%$ dan dosis 5\% meningkatkan jumlah anakan rumput Benggala (Tabel 3). Arang aktif sekam padi sebagai bahan organic pembenah tanah diduga dapat memperbaiki sifat fisik, kimia dan biologi tanah dan daya serap akar tanaman terhadap unsur hara tanah lebih baik sehingga jumlah anakan rumput Benggala semakin meningkat.

Tabel 3. Pengaruh arang aktif terhadap jumlah anakan

\begin{tabular}{|c|c|c|c|c|c|}
\hline $\begin{array}{c}\text { Waktu } \\
\text { Pengamatan }\end{array}$ & $\begin{array}{c}\text { Dosis } \\
\text { Arang aktif }\end{array}$ & \multicolumn{4}{|c|}{ Jenis arang aktif } \\
\hline (HST/anakan) & $(\%)$ & $\begin{array}{l}\text { Sekam } \\
\text { Padi }\end{array}$ & Tongkol Jagung & $\begin{array}{c}\text { Tempurung } \\
\text { Kelapa }\end{array}$ & Rerata \\
\hline \multirow{4}{*}{45} & 0 & $2,00^{\mathrm{a}}$ & $2,00^{\mathrm{a}}$ & $2,25^{\mathrm{a}}$ & $2,08^{a}$ \\
\hline & 2,5 & $4,25^{\mathrm{a}}$ & $3,25^{\mathrm{a}}$ & $4,00^{\mathrm{a}}$ & $3,83^{\mathrm{b}}$ \\
\hline & 5 & $3,75^{\mathrm{a}}$ & $3,75^{\mathrm{a}}$ & $3,25^{\mathrm{a}}$ & $3,58^{b}$ \\
\hline & Rerata & $3,33^{\mathrm{a}}$ & $3,00^{\mathrm{a}}$ & $3,17^{\mathrm{a}}$ & \\
\hline \multirow{4}{*}{90} & 0 & $2,75^{\mathrm{a}}$ & $1,00^{\mathrm{a}}$ & $2,00^{\mathrm{a}}$ & $1,92^{\mathrm{a}}$ \\
\hline & 2,5 & $3,00^{\mathrm{a}}$ & $3,25^{\mathrm{a}}$ & $3,50^{\mathrm{a}}$ & $3,25^{\mathrm{b}}$ \\
\hline & 5 & $4,25^{\mathrm{a}}$ & $3,50^{\mathrm{a}}$ & $3,75^{\mathrm{a}}$ & $3,83^{b}$ \\
\hline & Rerata & $3,33^{\mathrm{a}}$ & $2,58^{\mathrm{a}}$ & $3,08^{\mathrm{a}}$ & \\
\hline
\end{tabular}

Keterangan: Angka yang diikuti huruf yang sama menunjukan hasil berbeda tidak nyata dengan uji lanjut Duncan Multiple Range Test (DMRT) dengan tingkat signifikan 5\% dan HST: Hari Setelah Tanam.

Penambahan arang aktif sekam padi sebagai pembenah tanah dapat meningkatkan kandungan nutrisi dalam tanah seperti $\mathrm{N}$, Pdan $\mathrm{K}$ yang dapat meningkatkan serapan haradan bermanfaat bagi pertumbuhan tanaman (Majoret al.,2010). Hasil penelitian arang aktif sekam padi $5 \mathrm{Mg} \mathrm{ha}^{-1}, 10 \mathrm{Mg}^{-}$ ${ }^{1}$ dengan beberapa jenis dosis pupuk urea yang berbeda meningkatkan jumlah anakan 
pada persamaian tanaman padi (Denielet al., 2018).

Sekam sebagai media tanam yang mudah mengikat air, tidak mudah lapuk, merupakan sumber kalium (K) yang dibutuhkan tanaman, dan tidak mudah menggumpal atau memadat sehingga akar tanaman dapat tumbuh dengan sempurna (Perwtasari, 2012). Aplikasi arang aktif meningkatkan jumlah dan aktivitas biologis tanah yang bermuara pada peningkatan produksi tanaman (Paz-Ferreiroet al., 2016). Penambahan arang aktif di tanah sangat berguna untuk memperbaiki kualitas tanah, merangsang pertumbuhan tanaman, dan mempunyai peran penting memperbaiki tanah yang terkontaminasi (Placeket al., 2016). Hasil penelitian penambahan arang aktif sekampadi + limbahkarpet $(2+1 \mathrm{t})$ ha ${ }^{1}$ meningkatkan jumlah anakan tanaman padi (Oryza sativa) menunjukkan 19,2 pada umur 30 hari(D. K et al., 2017).

\section{Berat Segar Daun}

Berat segar daun rumput Benggala menunjukkan arang aktif tongkol jagung 5\% memiliki nilai lebih tinggi dari semua jenis arang aktif (Tabel4). Unsur hara C-organik $25,86 \%$ dalam arang aktif tongkol jagung diduga dapat memperbaiki kesuburan tanah sehingga meningkatkan hasil panen berat segar daun rumput Benggala.

Tabel 4. Pengaruh arang aktif terhadap berat segar daun

\begin{tabular}{cccccc}
\hline $\begin{array}{c}\text { Masa } \\
\text { Produksi }\end{array}$ & $\begin{array}{c}\text { Dosis } \\
\text { Arang aktif }\end{array}$ & & & Jenis arang aktif & \\
\hline (HST/g) & $(\%)$ & $\begin{array}{c}\text { Sekam } \\
\text { Padi }\end{array}$ & $\begin{array}{c}\text { Tongkol } \\
\text { Jagung }\end{array}$ & $\begin{array}{c}\text { Tempurung } \\
\text { Kelapa }\end{array}$ & Rerata \\
\hline \multirow{4}{*}{45} & 0 & $10,89^{\mathrm{a}}$ & $5,27^{\mathrm{a}}$ & $5,46^{\mathrm{a}}$ & $7,21^{\mathrm{a}}$ \\
& 2,5 & $8,74^{\mathrm{a}}$ & $15,90^{\mathrm{b}}$ & $10,10^{\mathrm{ab}}$ & $11,58^{\mathrm{b}}$ \\
& 5 & $17,47^{\mathrm{a}}$ & $18,37^{\mathrm{a}}$ & $16,06^{\mathrm{a}}$ & $17,30^{\mathrm{c}}$ \\
\cline { 2 - 6 } & Rerata & $12,37^{\mathrm{a}}$ & $13,18^{\mathrm{a}}$ & $10,54^{\mathrm{a}}$ & \\
\cline { 2 - 6 } 90 & 0 & $13,14^{\mathrm{a}}$ & $9,07^{\mathrm{a}}$ & $8,42^{\mathrm{a}}$ & $10,21^{\mathrm{a}}$ \\
& 2,5 & $15,40^{\mathrm{a}}$ & $12,26^{\mathrm{a}}$ & $13,48^{\mathrm{a}}$ & $13,71^{\mathrm{b}}$ \\
& 5 & $17,78^{\mathrm{a}}$ & $17,33^{\mathrm{a}}$ & $20,40^{\mathrm{a}}$ & $18,50^{\mathrm{c}}$ \\
\cline { 2 - 6 } & Rerata & $15,44^{\mathrm{a}}$ & $12,89^{\mathrm{a}}$ & $14,10^{\mathrm{a}}$ & \\
\hline
\end{tabular}

Keterangan: Angka yang diikuti huruf yang sama menunjukan hasil berbeda tidak nyata dengan uji lanjut Duncan Multiple Range Test (DMRT) dengan tingkat signifikan 5\% dan HST: Hari Setelah Tanam.

Aplikasi arang aktif pada tanah meningkatkan retensi air, $\mathrm{pH}$, konsentrasi nutrisi yang tersedia, kapasitas pertukaran kation dan pengurangan kepadatan curah tanah dan penyerapan fosfor yang lebih tinggi oleh tanaman (Hammer, 2014). Hasil penelitian penambahan arang aktif tongkol jagung 25 g polybag- $1+$ urea 1,5 g polybag1) di tanah netral $10 \mathrm{~kg}$ terhadap tanaman jagung meningkatkan berat brangkasan basah setelah panen (Hadi dan Wani, 2018). Arang aktif tempurung kelapa 5\% memiliki nilai lebih tinggi dari semua jenis arang terhadap berat segar daun rumput Benggala masa produksi II (Tabel4)

Arang aktif yang dikomposkan memiliki tingkat KTK yang tinggi, meningkatkan daya serap air, meningkatkan $\mathrm{pH}$ tanah dan akhirnya meningkatkan hasil tanaman(Ekebafeet al, 2015). Hasil penelitian penambahan arang aktif tempurungkelapa50 g/polybag pada pembibitan kelapa sawit (ElaeisguineensisJacq.) meningkatkan bobot segar tanaman(Guzaliet al., 2016). 


\section{Berat Kering Daun}

Arang aktif tongkol jagung 5\% memiliki nilai lebih tinggi terhadap berat kering daun rumput Benggala pemotongan I (Tabel 5).

Tabel 5. Pengaruh arang aktif terhadap berat kering

\begin{tabular}{|c|c|c|c|c|c|}
\hline $\begin{array}{c}\text { Masa } \\
\text { Produksi }\end{array}$ & & $\begin{array}{l}\text { Dosis } \\
\text { ang aktif }\end{array}$ & \multicolumn{3}{|c|}{ Jenis arang aktif } \\
\hline (HST/g) & $(\%)$ & $\begin{array}{l}\text { Sekam } \\
\text { Padi }\end{array}$ & Tongkol Jagung & $\begin{array}{c}\text { Tempurung } \\
\text { Kelapa }\end{array}$ & Rerata \\
\hline \multirow{4}{*}{45} & 0 & $3,42^{\mathrm{a}}$ & $1,77^{\mathrm{a}}$ & $1,77^{\mathrm{a}}$ & $2,32^{\mathrm{a}}$ \\
\hline & 2,5 & $2,73^{\mathrm{a}}$ & $4,91^{\mathrm{b}}$ & $3,14^{\mathrm{a}}$ & $3,59^{b}$ \\
\hline & 5 & $5,25^{\mathrm{a}}$ & $5,47^{\mathrm{a}}$ & $5,38^{\mathrm{a}}$ & $5,37^{\mathrm{c}}$ \\
\hline & Rerata & $3,80^{\mathrm{a}}$ & $4,05^{\mathrm{a}}$ & $3,43^{\mathrm{a}}$ & \\
\hline \multirow{4}{*}{90} & 0 & $3,44^{\mathrm{a}}$ & $2,52^{\mathrm{a}}$ & $2,39^{\mathrm{a}}$ & $2,78^{\mathrm{a}}$ \\
\hline & 2,5 & $4,08^{\mathrm{a}}$ & $2,98^{\mathrm{a}}$ & $3,53^{\mathrm{a}}$ & $3,53^{\mathrm{b}}$ \\
\hline & 5 & $4,21^{\mathrm{ab}}$ & $3,67^{\mathrm{a}}$ & $4,99^{\mathrm{b}}$ & $4,29^{c}$ \\
\hline & Rerata & $3,91^{\mathrm{b}}$ & $3,05^{\mathrm{a}}$ & & \\
\hline
\end{tabular}

Keterangan: Angka yang diikuti huruf yang sama menunjukan hasil berbeda tidak nyata dengan uji lanjut Duncan Multiple Range Test (DMRT) dengan tingkat signifikan 5\%

Peningkatan berat kering tanaman menunjukkan bahwa tanaman mengalami pertumbuhan dan perkembangan semakin meningkat (Evan et al., 2013). Arang aktif mengandung bahan organik dan unsur-unsur hara sehingga pemanfaatan arang aktif dapatmeningkatkan $\mathrm{pH}$ tanah, karbon organik (C), nitrogen total (TN), fosfor (P), dan kapasitas pertukaran kation (Dumeet al., 2016). Hasil penelitian penambahan arang aktif tongkol jagunng18 $\mathrm{t} \mathrm{ha}^{-1}+2 \mathrm{~kg}$ nitrogen, phosphorus, sulphur (NPS) meningkatkan biomassa kering tanaman Pisum sativum L (Tariku et al., 2017).

Berat kering daun rumput Benggala menunjukan penggunaan arang aktif tempurung kelapa 5\% memiliki nilai lebih tinggi dari semua jenis arang aktif (Tabel5). Porositas arang aktif tempurung kelapa diduga cukup luas sehingga mampu menyerap dan menyimpan hara dan air untuk kebutuhan tanaman. Arang aktif tempurung kelapa memiliki porosity $0.18 \%$ dan total pore Volume $0.15 \mathrm{~m}^{3}$ (Shanthi et al., 2017).
Arang aktif memiliki kandungan karbon yang tinggi dan bersifat porous yang apabila diaplikasikan ke tanah akan meningkatkan kesuburan tanah dan meningkatkan produktifitas pertanian (Igalavithana, 2016). Penggunaan arang aktif tempurung kelapa sebagai media tanam dapat meningkatkan berat kering daun tanamanCanna indica $\mathrm{L}$ (Shyamala dan $\mathrm{R}$ Joel., 2017).

\section{Protein Kasar}

Kandungan protein kasar rumput Benggala dianalisis pada umur masa panen 60 hari penambahan arang aktif pada media tanam rumput Benggala tidak menghasilkan peningkatan kualitas protein kasar (Tabel6). Hal ini disebabkanoleh media tanam yang terlihat lebih lembab akibat tingginya curah hujans elama penelitian sehingga diduga proses reaksi kimia tanaman kurang berjalan dengan lancar. 
Tabel 6. Pengaruh arang aktif terhadap protein kasar

\begin{tabular}{lccccc}
\hline $\begin{array}{c}\text { Protein } \\
\text { Kasar }\end{array}$ & $\begin{array}{c}\text { Dosis } \\
\text { Arang aktif }\end{array}$ & & & Jenis arang aktif & \\
\hline \multirow{2}{*}{$(\mathrm{HST} / \%)$} & $(\%)$ & $\begin{array}{c}\text { Sekam } \\
\text { Padi }\end{array}$ & $\begin{array}{c}\text { Tongkol } \\
\text { Jagung }\end{array}$ & $\begin{array}{c}\text { Tempurung } \\
\text { Kelapa }\end{array}$ & Rerata \\
\hline \multirow{2}{*}{45} & 0 & $9,54 \mathrm{a}$ & $11,08 \mathrm{~b}$ & $11,24 \mathrm{~b}$ & $10,62 \mathrm{~b}$ \\
& 2,5 & $9,72 \mathrm{a}$ & $10,80 \mathrm{a}$ & $10,67 \mathrm{a}$ & $10,39 \mathrm{~b}$ \\
& 5 & $8,57 \mathrm{a}$ & $8,29 \mathrm{a}$ & $8,59 \mathrm{a}$ & $8,4 \mathrm{a}$
\end{tabular}

Keterangan: Angka yang diikuti huruf yang sama menunjukan hasil berbeda tidak nyata dengan uji lanjut Duncan Multiple Range Test (DMRT) dengan tingkat signifikan 5\% dan HST: Hari Setelah Tanam.

Meski arang aktif awal pengukuran dengan nilai $\mathrm{pH}$ cocok sebagai pembenah tanah yang asam dan terdegradasi, hal ini dapat menyebabkan defisiensi nutrisi pada tanaman, ketika tanah menjadi terlalu basa (Huntetal.,2010). Semakin tinggi suhu semakin tinggi $\mathrm{pH}$ arang aktif. $\mathrm{pH}$ arang aktif mempengaruhi toksisitas aluminium dan ketersediaan nutrisi dari tanah ke tanaman. Oleh karena itu perlu diselidiki lebih lanjut efek arang aktif pada produksi pertanian di bawah kondisi spesifik, seperti bahan baku yang tersediaan kondisi pirolisis, kondisi iklim,jenis tanah dan tanaman yang akan dibudidayakan (Isleyetal., 2017).

\section{Serat Kasar}

Penggunaan arang aktif tempurung kelapa 2,5\% memiliki nilai kandungan serat kasar lebih rendah dibandingkan $0 \%$ dan 5\% untuk setiap jenis arang aktif (Tabel 7). Dapat diduga bahwa kondisi tanah yang digunakan dalam penelitian memiliki sifat tidak netral yang berpengaruh terhadap produktivitas tanaman sesuiaSaarnioetal., (2013) melaporkan aplikasi arang aktif lebih cocok ditanah yang sifatnya netral sedangkan tanah yang kurang netral dapat berpengaruh terhadap produksi tanaman sehingga perlu dipahami terlebih dahulu reaksi arang aktif sebelum digunakan.

Tabel 7. Pengaruh arang aktif terhadap serat kasar

\begin{tabular}{cccccc}
\hline $\begin{array}{c}\text { Serat } \\
\text { Kasar }\end{array}$ & $\begin{array}{c}\text { Dosis } \\
\text { Arang aktif }\end{array}$ & \multicolumn{4}{c}{ Jenis arang aktif } \\
\hline (HST/\%) & $(\%)$ & Sekam Padi & $\begin{array}{c}\text { Tongkol } \\
\text { Jagung }\end{array}$ & $\begin{array}{c}\text { Tempurung } \\
\text { Kelapa }\end{array}$ & Rerata \\
\hline \multirow{3}{*}{45} & 0 & $31,30 \mathrm{a}$ & $30,68 \mathrm{a}$ & $30,54 \mathrm{a}$ & $30,84 \mathrm{a}$ \\
& 2,5 & $30,09 \mathrm{ab}$ & $31,24 \mathrm{~b}$ & $28,81 \mathrm{a}$ & $30,04 \mathrm{a}$ \\
& 5 & $30,37 \mathrm{a}$ & $32,70 \mathrm{ab}$ & $33,85 \mathrm{~b}$ & $32,31 \mathrm{~b}$ \\
& Rerata & $30,59 \mathrm{a}$ & $31,54 \mathrm{a}$ & $31,07 \mathrm{a}$ & \\
\hline
\end{tabular}

Keterangan: Angka yang diikuti huruf yang sama menunjukan hasil berbeda tidak nyata dengan uji lanjut Duncan Multiple Range Test (DMRT) dengan tingkat signifikan 5\% dan HST: Hari Setelah Tanam.

Konsekuensi

penambahanarangaktifpada produktivitas tanaman tergantung padajumlah yang ditambahkan. Taraf aplikasi disarankan untuk setiap pembenah tanah dilakukan padapengujian lapangan yang luas (Jyoti et al.,2019). Selain disebabkan oleh faktor- faktor lain jenis arang aktif harus dipilih terlebih dahulu berdasarkan pengaruh pada ketersediaan hara di tanah sebelum diaplikasikan ke lahan (Alburquerqueetal., 2014). 


\section{Berat Segar Akar}

Penggunaan arang aktif tongkol jagung 5\% memiliki nilai lebih tinggi dari $0 \%$ dan
$2,5 \%$ terhadap berat segar akar rumput Benggala umur 90 hari (Tabel 8).

Tabel 8. Pengaruh arang aktif terhadap berat segar akar

\begin{tabular}{cccccc}
\hline $\begin{array}{c}\text { Waktu } \\
\text { Pengamatan }\end{array}$ & \multicolumn{3}{c}{$\begin{array}{c}\text { Dosis } \\
\text { Arang aktif }\end{array}$} & \multicolumn{2}{c}{ Jenis arang aktif } \\
\hline$($ HST/g) & $(\%)$ & Sekam Padi & Tongkol Jagung & $\begin{array}{c}\text { Tempurung } \\
\text { Kelapa }\end{array}$ & Rerata \\
\hline \multirow{3}{*}{90} & 0 & $26,66^{\mathrm{b}}$ & $18,47^{\mathrm{a}}$ & $15,33^{\mathrm{a}}$ & $20,15^{\mathrm{a}}$ \\
& 2,5 & $29,84^{\mathrm{a}}$ & $32,86^{\mathrm{a}}$ & $27,68^{\mathrm{a}}$ & $30,12^{\mathrm{b}}$ \\
& 5 & $35,05^{\mathrm{ab}}$ & $36,60^{\mathrm{b}}$ & $29,79^{\mathrm{a}}$ & $33,82^{\mathrm{b}}$ \\
& Rerata & $30,51^{\mathrm{b}}$ & $29,31^{\mathrm{b}}$ & $24,26^{\mathrm{a}}$ & \\
\hline
\end{tabular}

Keterangan: Angka yang diikuti huruf yang sama menunjukan hasil berbeda tidak nyata dengan uji lanjut Duncan Multiple Range Test (DMRT) dengan tingkat signifikan 5\% dan HST: Hari Setelah Tanam.

Arang memiliki pori-pori kecil yang sangat banyak pori-pori ini sangat efektif untuk mengikat dan menyimpan hara tanah yang akan dilepaskan secara perlahan sesuai konsumsi dan kebutuhan tanaman (slow release) (Gusmailinaet al., 2015). Hasil penelitian penambahan arang aktif tongkol jagung12 $\mathrm{t} \mathrm{ha}^{-1}+2 \mathrm{~kg}$ nitrogen, phosphorus, sulphur (NPS) meningkatkan berat segar akar tanaman Pisum sativum L pada umur 30 hari (Tariku et al., 2017).

\section{Berat Kering Akar}

Arang aktif sekam padi 5\% memiliki nilai tertinggi terhadap berat kering akar rumput Benggala umur 90 hari (Tabel 9).

Tabel 9. Pengaruh arang aktif terhadap berat kering akar

\begin{tabular}{cccccc}
\hline $\begin{array}{c}\text { Waktu } \\
\text { Pengamatan }\end{array}$ & $\begin{array}{c}\text { Dosis } \\
\text { Arang aktif }\end{array}$ & \multicolumn{3}{c}{ Jenis arang aktif } \\
\hline \multirow{2}{*}{$(\mathrm{HST})$} & $(\%)$ & $\begin{array}{c}\text { Sekam } \\
\text { Padi }\end{array}$ & Tongko 1Jagung & $\begin{array}{c}\text { Tempurung } \\
\text { Kelapa }\end{array}$ & Rerata \\
\hline 90 & 0 & $4,94^{\mathrm{a}}$ & $4,28^{\mathrm{a}}$ & $3,16^{\mathrm{a}}$ & $4,13^{\mathrm{a}}$ \\
& 2,5 & $5,89^{\mathrm{a}}$ & $6,35^{\mathrm{a}}$ & $5,31^{\mathrm{a}}$ & $5,85^{\mathrm{b}}$ \\
& 5 & $7,84^{\mathrm{a}}$ & $7,81^{\mathrm{a}}$ & $6,59^{\mathrm{a}}$ & $7,41^{\mathrm{c}}$ \\
\end{tabular}

Keterangan: Angka yang diikuti huruf yang sama menunjukan hasil berbeda tidak nyata dengan uji lanjut Duncan Multiple Range Test (DMRT) dengan tingkat signifikan 5\% dan HST: Hari Setelah Tanam.

Penambahan arang sekam padi ke dalam tanah dapat meningkatkan $\mathrm{pH}$ tanah, porositastanah, kalium $(\mathrm{K})$, magnesium $(\mathrm{Mg})$ serta tersedianya fosfor $(\mathrm{P})$ dan air untuk tanaman (Varela et al., 2013). Arang aktif sekam padi $5 \mathrm{Mg} \mathrm{ha}^{-1}$ dengan beberapa jenis dosis pupuk urea.

\section{KESIMPULAN}

Pertumbuhan dan produktivitas rumput Benggala tergantung ketersediaan unsur hara dalam tanah. Penggunaan arang aktif untuk pembenah tanah sangat mendukung kesuburan lahan tanaman makanan ternak. Arang aktif seperti sekam padi, tongkol jagung dan tempurung kelapa dimanfaatkan sebagai media tanam berpengaruh terhadap tinggi tanaman, jumlah anakan, berat segar 
daun, berat kering daun, berat segar akar dan berat kering akar rumput Benggala masa produksi I dan II. Selain itu untuk setiap jenis arang aktif dengan dosis yang berbeda tidak mempengaruhi kandungan protein kasar namun meningkatkan serat kasar tanaman rumput Benggala.

\section{DAFTAR PUSTAKA}

Albert, Kobina, Mensah and Kwame, Agyei, Frimpong. 2018. Biochar and/or Compost Applications Improve Soil Properties, Growth, and Yield of Maize Grown in Acidic Rainforest and Coastal Savannah Soils in Ghana. Department of Soil Science and Soil Ecology, Institute of Geography, RuhrUniversitaet Bochum, Universit" atsstraße $\quad 150,44801$ Bochum, Germany, Department of Soil Science, School of Agriculture, University of Cape Coast, Cape Coast, Ghana. Hindawi: International Journal of Agronomy, Volume 2018, Article ID 6837404,8 pages.

Alburquerque, J. A., Calero, J. M., Barrón, V., Torrent, J., del Campillo, M. C., Gallardo, A and Villar,R. 2014. Effects Of Biochars Produced From Different Feedstocks On Soil Properties And Sunflower Growth. Journal of Plant Nutrition and Soil Science, 177(1), pp. 16-25.

Alfarisi., Nurcholis and Manurung., Toyo. 2015. Pengaruh Pemberian Pupuk Urin Sapi Terhadap Pertumbuhan dan Produksi Jagung Manis (Zea mays saccharata) Dengan Penggunaan EM4: Jurnal Biosains Vol. 1 No. 3. Issn. 2443-1230 (cetak) Issn. 24606804.

Arif, A., Sugiharto, A.N. dan Widaryanto, E. 2014. Pengaruh Umur Transplanting Benih Dan Pemberian Berbagai Macam Pupuk Nitrogen Terhadap
Pertumbuhan Dan Hasil Tanaman Jagung Manis (Zea mays L. saccharata Strut). Jurnal ProduksiTanaman2(1): 2-8.

Bonanomi, G., Ippolito, F., Cesarano, G., Nanni., B, Lombardi, N and Rita, A. 2017. Biochar As Plant Growth Promoter: Better Off Alone Or Mixed With Organic Amendments? Frontiers In Plant Science.;8:1570. DOI: 10.3389/ fpls.2017.01570.

D. K. Singhal., JanardanYadav., Shiv, Singh,Meena and Divyesh, Chandra, Kala. 2017. Effect Of Rice Husk Biochar, Carpet Waste, Farm Yard Manure And Plant Growth Promoting Rhizobium On The Growth And Yield Of Rice (Oryza sativa) . ${ }^{1,} \quad 2$, ${ }^{3}$ Department of Soil Science and Agricultural Chemistr, Banaras Hindu University, Varanasi (U.P.), ${ }^{4}$ Department of Soil Science, College of Agriculture, GBPUA \&T, Pantnagar, U. S. Nagar (Uttarakhand), India. Journal of Applied and Natural Science 9 (4): 2043 -2046. Issn : 09749411 (Print), 2231-5209 (Online).

Deniel, S., Rosenani, A.B., Ahmad, S.H and Abdul Rahim K.B. 2018. Influences Of Rice Husk Biochar (Rhb) On Rice Growth Performance And Fertilizer Nitrogen Recovery Up To Maximum Tillering Stage. ${ }^{1}$ Department of Soil Management, Faculty of Agriculture, Universiti Putra Malaysia, ${ }^{2}$ Division of Agrotechnology and Biosciences, Malaysian Nuclear Agency, Malaysia. .ISSN: 2354-5844 (Print), ISSN: $2477-$ 5223 (Online).

Dewi, Ekowati and Inaratul, Rhizky, Hanifah. 2016. Potensi Tongkol Jagung (Zea Mays L.) Sebagai Sunscreen Dalam Sediaan Hand Body Lotion. FakultasFarmasi, Universitas 
Setia Budi. JurnalIlmiahManuntung, 2(2), 198-207,Issn cetak. 2443-115x, Issn Elektronika. 2477-1821

Dume, B., Mosissa, T andNebiyu, A. 2016. Effect Of Biochar On Soil Properties And Lead $(\mathrm{Pb})$ Availability In A Military Camp In South West Ethiopia. African Journal of Environmental Science and Technology; 10 (3) :77-85

E.D. Purbajanti, R.D.Soetrisno, E.Hanudin, dan S.P.S.Budhi. 2010. Penampilan Fisiologi Dan Hasil Rumput Benggala (Panicum maximum Jacq.) Pada Tanah Salin Akibat Pemberian Pupuk Kandang, Gypsum Dan Sumber Nitrogen. Fakultas Peternakan Universitas Diponegoro, J1.ProfSudharto SH, Semarang, FakultasPeternakanUniversitas Gadjah Mada, Karangmalang, Yogyakarta, FakultasPertanianUniversitas Gadjah Mada, Bulaksumur, Yogyakarta. JIPI. 12 (1): 61-67 (2010), ISSN 1411 0067.

Ekebafe, M.O. Ekebafe, L.O and Ugbesia, S.O. 2015. Biochar Composts And Composites. Science Progress 98(2), 169-176.

Evan, Mungara1., Didik, Indradewa2., and Rohlan, Rogomulyo. 2013. Analisis Pertumbuhan Dan Hasil PadiSawah (Oryza Sativa L.) Pada Sistem Pertanian Konvensional, Transisi Organik, Dan Organik. Fakultas Pertanian Universitas Gadjah Mada, Yogyakarta. Vegetalika Vol.2 No.3, $2013: 1-12$

Gusmailina., Komarayati, Sri and Pari, Gustan. 2015. Membangun Kesuburan Tanah Dengan Arang. Pusat Penelitian dan Pengembangan HasilHutan .Bogor.
Guzali., Adiwirman and Wawan. 2016. Pengunaan Biochar Berbahan Baku Tempurung Kelapa dan Pelepah Sawit pada Pembibitan Utama Kelapa Sawit (ElaeisguineensisJacq.) di Medium Gambut. Program Studi Master Ilmu Pertanian Fakultas Pertanian, Universitas Riau. JurnalAgrotek. Trop. 5 (2): 55-61.

Hadi, Yuananto and Wani, Hadi, Utomo. 2018. Pengaruh Aplikasi Biochar Tongkol Jagung Diperkaya Asam Nitrat Terhadap Kadar C-Organik, Nitrogen, Dan Pertumbuhan Tanaman Jagung Pada Berbagai Tingkat Kemasaman Tanah. JurusanTanah, FakultasPertanian, Universitas Brawijaya. Jurnal Tanah dan Sumberdaya Lahan,Vol 5 No 1 : 655662, e-Issn:2549-9793.

Hunt, J., DuPonte, M., Sato, D and Kawabata, A. (2010). The Basics Of Biochar: A Natural Soil Amendment. Soil Crop Manage. SCM-30.

Igalavithana, A.D., Ok, Y.S., Usman, A.R.A., Al-Wabel, M.I. Oleszczuk, P and Lee, S.S. 2016. The Effects of Biochar Amendment on Soil Fertility. Agricultural and Environmental Application of Biochar: Advances and Barriers. SSSA Special Publication.

Isley, Cristiellem, Bicalho, da Silva., Luiz, Arnaldo, Fernandes., Fernando, Colen and Regynaldo Arruda Sampaio. 2017. Growth and production of common bean fertilized with biochar. Instituto de CiênciasAgrárias, Universidade Federal de Minas Gerais (UFMG), Campus Montes Claros, 39404-547, Montes Claros, MG, Brasil.Ciência Rural, v.47, n.11.Issne 1678-4596.

Jyoti, Rawat., Jyoti, Saxena and Pankaj, Sanwal. 2019. Biochar: A Sustainable 
Approach For Improving Plant Growth And Soil Properties. 1 Department of Biotechnology, Kumaun University, Bhimtal Campus, Nainital,India 2 Biochemical Engineering Department, B.T. Kumaon Institute of Technology,Dwarahat, India.

K, Angalaeeswari\& SPB, Kamaludeen. 2017. Production And Characterization Of Coconut Shell And Mesquite Wood Biochar. Department of Environmental Sciences, TNAU, Coimbatore, Tamil $\mathrm{Nadu}$, India. International Journal of Chemical Studies 2017; 5(4): 442-446. P-Issn: 2349-8528, E-Issn: 23214902.

Kusuma, Erviana, Maria. 2017. Respon Rumput Meksiko (Euchlaenamexicana) Terhadap Pemberian Kompos Rumen pada Tanah Berpasir. Fakultas Peternakan Universitas Kristen Palangka Raya. Jurnal Ilmu Hewani TropikaV ol 6. No. 2, Issn : 2301-7783.

Major, J. 2009. Biochar belongs in soil. National Society of Consulting Soil Scientists, Inc. Website http://www.nscss.org/node/187.

Diakses 21 April 2019

Miranti, Ayu, Verdiana., Husni, Thamrin, Sebayang and Titin, Sumarni. 2016. Pengaruh Berbagai Dosis Biochar SekamPadi Dan Pupuk NPK TerhadapPertumbuhan Dan Hasil TanamanJagung (Zea mays L.). Jurusan Budidaya Pertanian Fakultas Pertanian Universitas Brawijaya. Jurnal Produksi Tanaman Vol. 4 No. 8, : 611-616, Issn: 2527-8452.

Paz-Ferreiro, J., Mendez, A andGasco, G. 2016. Application Of Biochar For Soil Biological Improvement. Agricultural And Environmental Application Of
Biochar: Advances And Barriers. SSSA Special Publication.

Placek, A., Grobelak, A and Kacprzak M. 2016. Improving The Phytoremediation Of Heavy Metals Contaminated Soil By Use Of Sewage Sludge. International Journal of Phytoremediation; 18(6):605-618

Perwtasari, B. 2012. Pengaruh Media Tanam Dan NutrisiTerhadapPertumbuhan Dan Hasil TanamanPakchoi (Brassica junceaL.) DenganSistemHidroponik. Agrovigor. Volume 5 No. 1.

Saarnio, S., Heimonen, K and Kettunen R. 2013. Biochar Addition Indirectly Affects N2O Emissions Via Soil Moisture And Plant N Uptake. Soil Biology And Biochemistry. ;58:99-106

Shanthi, Prabha ,V., Sreekanth, N.P, Babu., Padmakumar and A.P, Thomas. 2017. Characterization Of Selected Biochars To Determine Their Suitability As A Soil Amendment From A Climate Change Mitigation Perspective.Advanced Centre of Environmental Studies and Sustainable Development, School of Environmental Sciences, M.G University, Kottayam - 686560, Kerala, India. International PeerReviewed Journal, Oct. Jour. Env. Res. Vol. 5(1): 053-063,Issn 23213655.

Shyamala, Lionel and R, Joel Karunakaran. 2017. A Comparative Study Of Two Biochars Based On The Temperature Of Pyrolysis For Phytoremediation Of Chromium Spiked Soil By Canna indicaL. Department of Chemistry, Madras Christian College, Chennai, Tamil Nadu,India. Journal of Pharmacognosy and Phytochemistry; 6(5): 104-111. E-Issn: 2278-4136, PIssn: 2349-8234. 
Sismiyanti., Hermansah and Yulnafatmawita. 2018. Klasifikasi Beberapa Sumber Bahan Organik Dan Optimalisasi Pemanfaatannya Sebagai Biochar. Program Magister Ilmu Tanah Jurusan Tanah Fakultas Pertanian Universitas Andalas. JurnalSolum Vol.XV No. 1: 8-16, PIssn 1829-7994, E-Issn 2356-083.

T. Dhalika., A.Budiman and Mansyur. 2015. Kualitas Silase Rumput Benggala (Panicum maximum) Pada Berbagai Taraf Penambahan Bahan Aditif Ekstrak Cairan Asam Laktat ProdukFermentasi Anaerob Batang Pisang. Fakultas Peternakan Universitas Padjadjaran. JurnalPeternakan Indonesia, Vol. 17 (1), Issn 1907-1760.

Tariku, Berihun., Shiferaw, Tolosa., Muluken, Tadele and Firew Kebede. 2017. Effect of Biochar Application on Growth of Garden Pea (Pisum sativum L.) In Acidic Soils OfBule Woreda Gedeo Zone Southern Ethiopia. ${ }^{1}$ Department of Biology, Dilla University, ${ }^{2}$ Department of Plant Science, Dilla University, ${ }^{3}$ Department of Biology, Hawassa University, Ethiopia. Hindawi International Journal of Agronomy Volume 2017, Article ID 6827323, 8 pages
Tribuyeni., Syahrudin and Widiastuti. 2016. Pemberian Biochar Tempurung Kelapa Dan Pupuk Organik Cair Terhadap Pertumbuhan Dan Hasil KubisBunga (Brassica oleraceae var. botrytis L.) Pada Tanah Gambut Pedalaman. Jurusa Budidaya Pertanian Fakultas Pertanian Universitas Palangka Raya. Jurnal Agri Peat, Vol. 17 No. $1: 1$ - 10, Issn :1411 - 6782.

Varela, Milla., O, Rivera., E.B., Huang, W.J., Chien, C. and Wang, Y.M. 2013. Agronomic Properties And Characterization Of Rice Husk And Wood Biochars And Their Effect On The Growth Of Water Spinach In A Field Test. Journal of Soil Scienceand Plant Nutrition, 13, 251-266.

Widana, G.A.A.N.G.K.Roni and A.A.A.S. Trisnadewi. 2015. Pertumbuhan dan Produksi Benggala (Panicum Maximum cv Trichoglume) Pada Berbagai Jenis dan Dosis Pupuk Organik. Jurnal. Program Studi Peternakan, Fakultas Peternakan, UniversitasUdayana. Denpasar. Tropika Vol. 3 No. 2:405-417. 